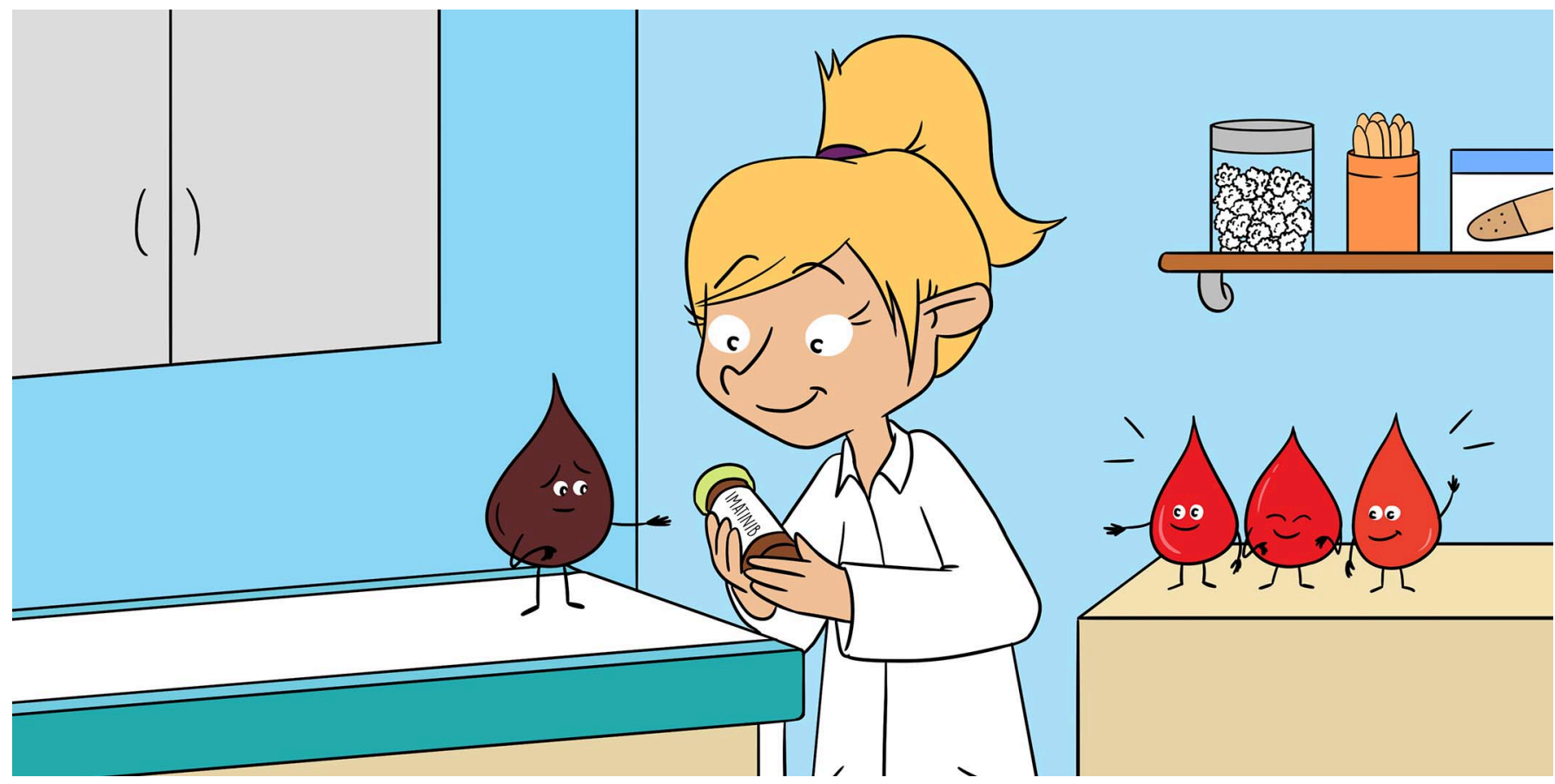

\title{
IMATINIB, THE MAGIC BULLET FOR TREATMENT OF BLOOD CANCER
}

\section{Maria Teresa Esposito*}

Health Science Research Centre, University of Roehampton, London, United Kingdom

\section{YOUNG REVIEWER:}

.

VAIGA

AGE: 9
DNA

A very long and tangled material that resembles a ball of wool. It is the material that carries all the information needed for the life and death of a cell.
Some say it is a magic bullet. Others refer to it as a miracle. Imatinib is a drug used to treat a type of blood cancer. Today, patients who take imatinib survive an average of 30 years. This means that most of them can live as long as any other person. This is amazing! In the 1980s, a cancer patient could expect to live only 3-5 years. Imagine how devastating this was for the patient and the patient's family! But how did we develop imatinib? Why is imatinib considered a miracle drug? And why is the story behind this drug so special? To answer these questions, we have to time travel to the past. This article describes the astonishing discovery of imatinib, the magic bullet for treatment of blood cancer, the efforts of the scientists behind this discovery, and what we have learned from the development of this drug.

\section{INTRODUCTION}

Since the discovery of DNA, the genetic code regulating the life and death of every cell, progress in medicine has flourished. As scientists, we understand diseases better and, therefore, we can develop better 
Figure 1

Blood drop in a healthy person and in a leukemic patient. In a blood drop from a healthy person, there are millions of red blood cells, hundreds of thousands of platelets, and thousands of white blood cells. In a leukemic patient's blood, cancer cells, called leukemic cells, emerge and crowd out the other blood cells.

\section{IMATINIB}

Is a drug inhibitor of BCR-ABL protein. It binds to $B C R-A B L$ and switches it off.

\section{CHRONIC MYELOID} LEUKEMIA (CML)

A blood cancer. In CML patients, the blood is full of cancer cells that occupy all the space normally taken up by functional blood cells.

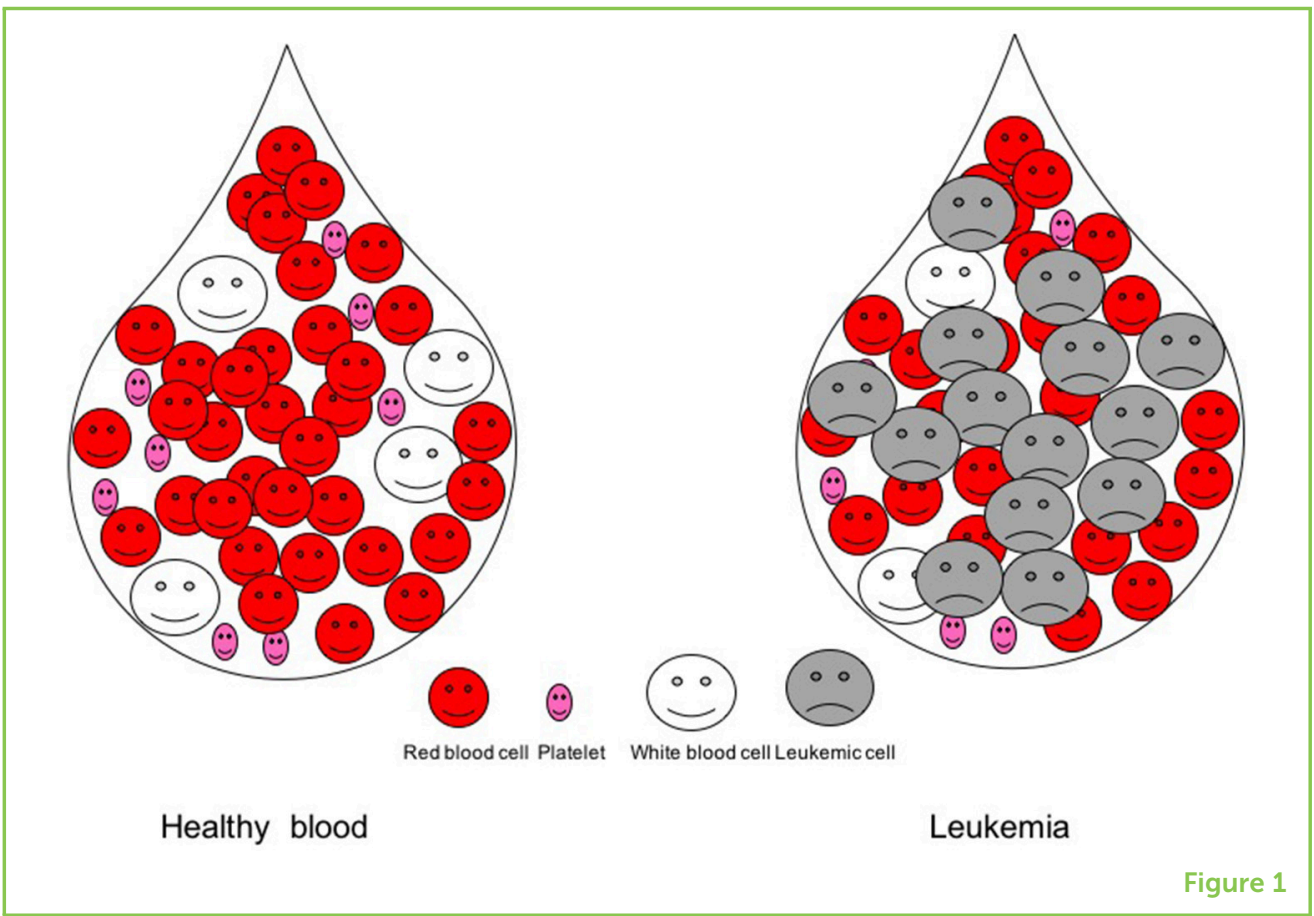

treatments. Cancer is a very serious disease. For decades, doctors have used nasty drugs to treat cancer. Some cancer-treating drugs are nasty because they do not distinguish cancer cells from healthy cells, so they kill both. This means that patients can become sick during the treatment. Imatinib is the first drug available to patients that have a rare form of cancer that affects blood cells. In this article, we will tell you about the amazing success of imatinib.

\section{LET US TALK ABOUT BLOOD CANCER. WHAT IS CHRONIC MYELOID LEUKEMIA?}

When you go to the doctor, you tell the doctor your symptoms and expect the doctor to come up with a diagnosis and prescribe you a treatment so that you get better. In 1845, two doctors, Drs. John Bennett in Edinburgh and Drs. Rudolph Virchow in Berlin, had patients whose blood was sick. They did not know what the disease was-it was not in their books. They were the first to describe the symptoms of this new disease. It was a blood cancer that is now known as chronic myeloid leukemia (CML) [1, 2].

In the blood, there are three type of cells: red blood cells (erythrocytes) carry oxygen toward the tissues and waste products, such as carbon dioxide, to the lungs; white blood cells (leucocytes) help defend us from infections; platelets (thrombocytes) build a natural plaster to seal up wounds. In CML patients, the blood is full of cancer cells that occupy all the space normally taken up by the useful types of blood cells (Figure 1). This is pretty much all that was known about this disease until 1956. 
Figure 2

Chromosomes, genes, and DNA. DNA is a very long, tangled material that resembles a ball of wool. The DNA contains all the information needed for the life and death of a cell. Inside human cells, the DNA is organized into 46 chromosomes. Each piece of information is carried on a different section of the chromosomes. These sections are called genes. Each gene is a unit that encodes for a protein with a specific function.

\section{CHROMOSOMES}

Structures made of wound-up DNA. Inside human cells, the DNA is organized into 46 chromosomes. Each chromosome contains hundreds of genes.

PHILADELPHIA CHROMOSOME

Is an abnormal small chromosome where a piece of chromosome 22 fuses with a piece of chromosome 9.

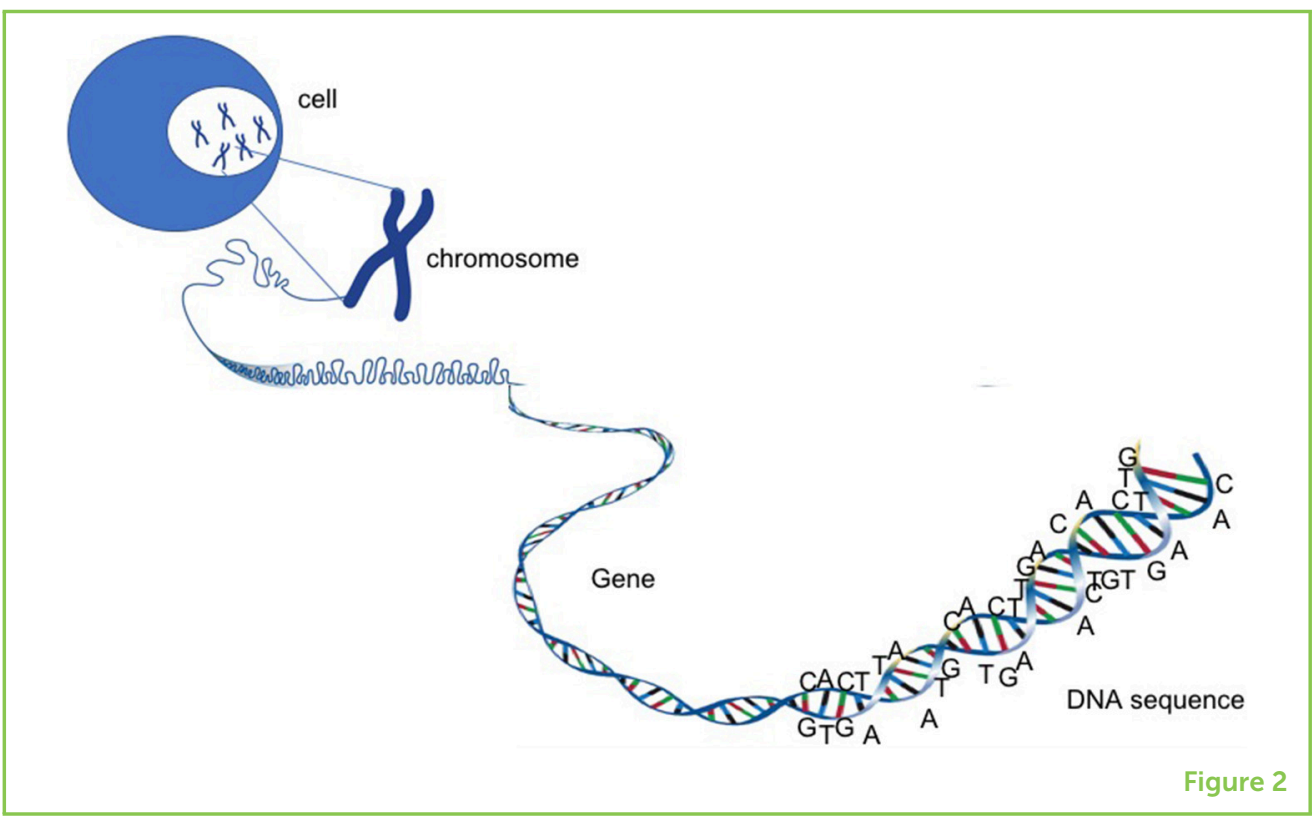

\section{WHAT MAKES BLOOD CELLS GO WRONG? A WEIRD CHROMOSOME}

It was only in the late 1950s that scientists started to understand what turned blood cells into CML cancer cells. In 1953, Drs. Rosalind Franklin, James Watson, and Francis Crick discovered the DNA, the genetic code in which all the information about a cell's life resides [3]. The discovery of DNA led to the development of new research areas and methods, which eventually helped scientists understand how DNA is packed into our cells and how it tells cells what to do. After all, if a cell turns into a cancer cell, something must be happening inside the cell that to make it that way!

In 1956, Drs. Joe Tjo and Albert Levan discovered that human DNA is packed in 46 chromosomes (Figure 2). Scientists started to use new methods to view and analyse chromosomes and to compare the chromosomes of cells from healthy people to those from patients affected by various diseases. This way, scientists learned that there are connections between abnormal chromosomes and various human diseases. For example, they discovered that children affected by Down syndrome have an extra copy of chromosome 21. Two scientists, Drs. Peter Nowell and David Hungerford, identified a connection between a chromosomal abnormality and CML. They noticed a strange looking, small chromosome in cancer cells from two patients with this disease. Was this just a coincidence? To answer this question, they analyzed five more patients with the same disease and found the same unusually small chromosome in these patients, too. This small chromosome was soon named the Philadelphia chromosome, after the city in which it was discovered (Figure 3). 
Figure 3

The Philadelphia chromosome. Healthy people carry 23 pairs of chromosomes (46 chromosomes total). (A) chromosomes, numbers 9 and 22 in healthy people, and two genes within these chromosomes, $A B L$ and BCR. (B) In leukemic patients, there is a change in the structure of chromosomes 9 and 22. During this change, a piece of chromosome 22 fuses with a piece of chromosome 9 . This gives rise to a small chromosome called the Philadelphia chromosome, within which the BCR and $A B L$ genes fuse to form $a$ new gene, known as $B C R-A B L$.

\section{GENES}

The basic unit of DNA. Each gene codes for a protein with a specific function.

\section{PROTEINS}

The building blocks to make everything in the body.

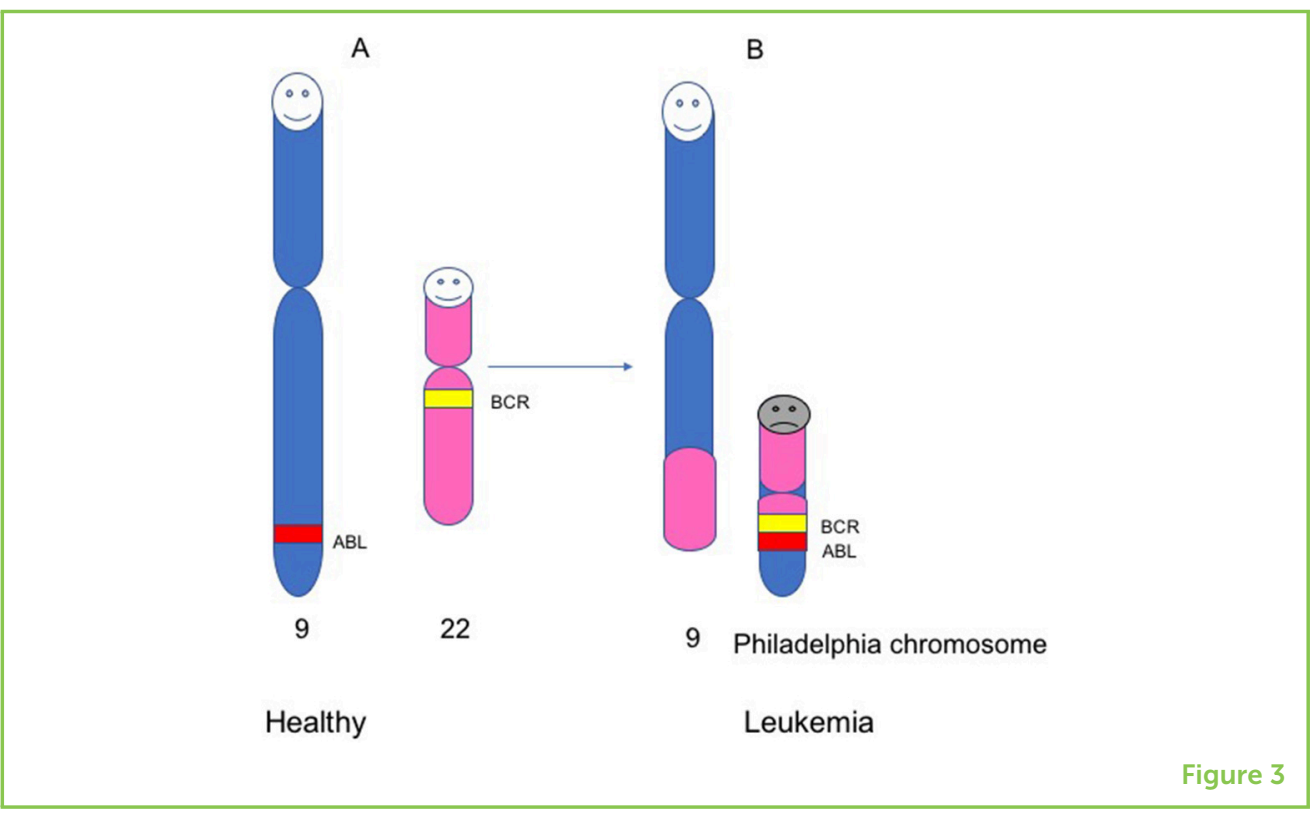

\section{LET US TAKE A CLOSER LOOK INTO THE PHILADELPHIA CHROMOSOME}

In the decades following the discovery of the Philadelphia chromosome, scientists became able to study the organization and structure of chromosomes through a microscope. This allowed scientists to understand which pieces of DNA were stuck together in the Philadelphia chromosome. For Dr. Janet Rowley, a biologist at the University of Chicago, it was like doing a jigsaw puzzle. Rowley analyzed cells from nine CML patients and discovered that the Philadelphia chromosome was made from a piece of chromosome 9 glued to chromosome 22 (Figure 3) [4]. As each chromosome is made up of hundreds of genes, it was likely that the fusion between chromosomes 9 and 22 fused two genes together. But which genes? It took another 10 years for scientists to answer this question. The conclusion of all these studies was that CML patients had a gene called BCR-ABL, which was created by the fusion of the BCR gene on chromosome 22 and the ABL gene on chromosome 9 (Figure 3).

\section{BAD GENES MAKE BAD PROTEINS}

Why is BCR-ABL bad? In 1990, scientists from the University of California learned the function of the BCR-ABL fusion gene. Genes contain the information needed for a cell to produce proteins. In cells, proteins do many things and can take part in cell growth and death. Growth and death are very important, so proteins that play a role in controlling cell growth and death need to be closely regulated. The normal growth of cells is regulated by proteins that work like traffic lights. When the light is green, the cells know that they can grow. When the light is red, the cells understand that they must stop 
growing. The BCR-ABL gene produces a protein that keeps the green light on and tells the cells to grow. In CML patients, the blood cells lose control of their growth and grow too fast, which is bad for the patient because the cancer cells crowd out the healthy and functional blood cells (Figure 1).

So, by 1990, scientists knew that the genes BCR and ABL are fused together in the Philadelphia chromosome and make an abnormal protein responsible for the fast growth of blood cells, which causes CML. The fact that CML is due to a single malfunctioning protein meant that drug developers had just one target to look at to cure CML: they had to shut down the BCR-ABL protein and turn the traffic light from green to red.

\section{FROM BASIC SCIENCE TO DRUG DISCOVERY}

Unfortunately, in the 1990s, shutting down a protein like BCR-ABL was not easy. There are hundred proteins similar to BCR-ABL in our cells. How could we possibly find a way to shut down BCR-ABL without shutting down all the other proteins, which could kill the patients?

As scientists learned more about the structure of BCR-ABL and similar proteins, they realized that these proteins were slightly different from each other and from BCR-ABL These details were fundamental for designing a drug against $B C R-A B L$.

An American doctor, Dr. Brian Druker, did some experiments in the laboratory to test possible drugs to treat CML. He found one drug that looked very promising. When he added the drug to the CML cells, they stopped growing. More importantly, when he added the drug to healthy cells, nothing happened. This meant that the drug was safe and did not harm healthy cells. This was exactly what Dr. Druker was looking for! With the help of a British doctor, Dr. John Goldman, Druker encouraged drug companies to produce this drug, which could shut down BCR-ABL.

\section{IMATINIB REACHES CML PATIENTS}

Two years later, in 2001, some CML patients took the drug in a clinical trial. Scientists use clinical trials to test new drugs on a small number of patients. The patients are monitored closely, blood tests are done, and if there is any reason to believe that the drug is toxic or is not working, the doctors can quickly stop the treatment. Dr. Druker and colleagues found that the drug killed the cancerous blood cells in nearly all the CML patients [5]. This response was astonishing. It was the first time that doctors observed such a response by administering only one anti-cancer drug to their patients, instead of many different, 
Figure 4

Mechanism of imatinib (A) The BCR-ABL gene encodes for the $B C R-A B L$ protein. When BCR-ABL is switched on, it keeps leukemic cells growing (B) Imatinib switches off BCR-ABL and kills the leukemic cells.
A

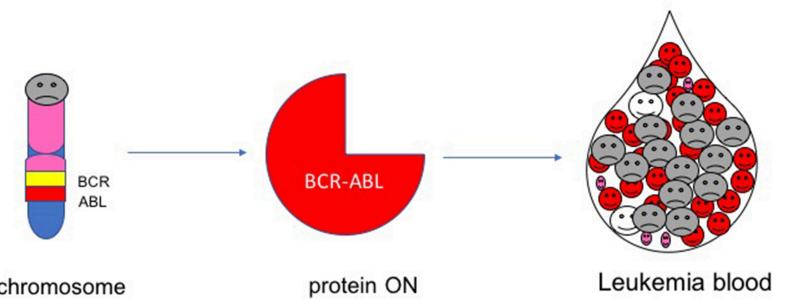

B
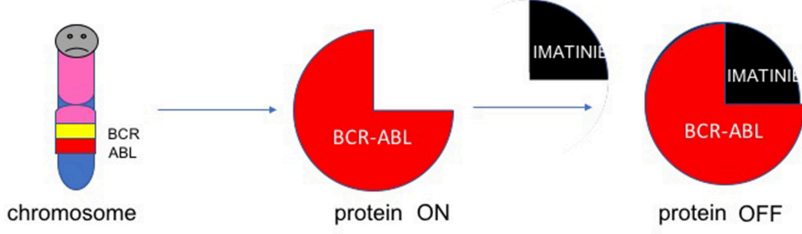

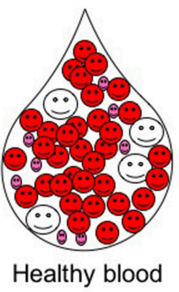

Figure 4

nasty ones! Dr. Druker's team continued to follow the patients for several years. Five years later, the patients still did not have any cancer cells in their blood (Figure 4). These results were impressive!

\section{CONCLUSIONS}

Imatinib was a ground-breaking discovery, not only because of the results it achieved and because it saved the lives of thousands of patients, but also because of the way this drug was developed and what scientists have learned from its development. Imatinib taught scientists that, by understanding the biology of a disease-what makes a cell "go wrong" somehow-it is possible to learn how to treat and cure the disease. This approach has since been used to develop drugs for other cancers, such as some forms of ovarian, skin, and lung cancer. It took 41 years from the discovery of BCR-ABL to the development of imatinib. Scientific progress is accelerating the speed of drug development. As scientists, we hope that this progress will more rapidly lead to successful stories, such as that of imatinib. Stay tuned!

\section{REFERENCES}

1. Pray, L. 2008. Gleevec: the breakthrough in cancer treatment. Nat. Educ. 1:37.

2. Mughal, T. I., Radich, J. P., Deininger, M. W., Apperley, J. F., Hughes, T. P., Harrison, C. J., et al. 2016. Chronic myeloid leukemia: reminiscences and dreams. Haematologica 101:541-58. doi: 10.3324/haematol.2015.139337

3. Watson, J., and Crick, F. 1953. A structure for deoxyribose nucleic acid. Nature 171:737-8. doi: 10.1038/171737a0

4. Rowley, J. D. 1973. A new consistent chromosomal abnormality in chronic myelogenous leukaemia identified by quinacrine fluorescence and Giemsa staining. Nature 243:290-3. doi: 10.1038/243290a0 
5. Druker, B. J, Talpaz, M., Resta, D. J., Peng, B., Buchdunger, E., Ford, J. M., et al. 2001. Efficacy and safety of a specific inhibitor of the BCR-ABL tyrosine kinase in chronic myeloid leukemia. N. Engl. J. Med. 344:1031-7.

doi: 10.1056/NEJM200104053441401

SUBMITTED: 27 July 2019; ACCEPTED: 05 February 2020;

PUBLISHED ONLINE: 26 February 2020.

EDITED BY: Fulvio D'Acquisto, Department of Life Sciences, University of Roehampton London, United Kingdom

CITATION: Esposito MT (2020) Imatinib, The Magic Bullet for Treatment of Blood Cancer. Front. Young Minds 8:17. doi: 10.3389/frym.2020.00017

CONFLICT OF INTEREST: The author declares that the research was conducted in the absence of any commercial or financial relationships that could be construed as a potential conflict of interest.

COPYRIGHT @ 2020 Esposito. This is an open-access article distributed under the terms of the Creative Commons Attribution License (CC BY). The use, distribution or reproduction in other forums is permitted, provided the original author(s) and the copyright owner(s) are credited and that the original publication in this journal is cited, in accordance with accepted academic practice. No use, distribution or reproduction is permitted which does not comply with these terms.

\section{YOUNG REVIEWER}

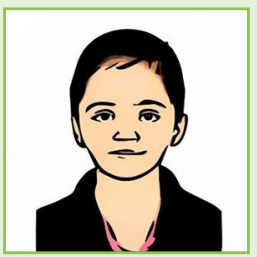

\section{VAIGA, AGE: 9}

Fun-loving, sensitive, and inquisitive, always on a quest for something new. Aim to reach the stars.

\section{AUTHOR}

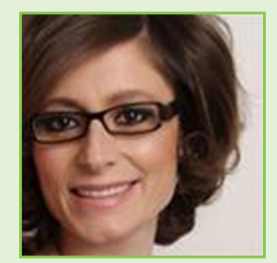

\section{MARIA TERESA ESPOSITO}

Maria Teresa Esposito is a Senior Lecturer in Biomedical Science at the University of Roehampton. She holds a Bachelor degree in Medical Biotechnologies and a Ph.D. in Molecular Medicine. She was trained in hemato-oncology at the Institute of Cancer Research and King's College London. At the University of Roehampton she teaches cellular, molecular biology, and hematology. Her research focuses on mechanisms of chemotherapy resistance of Leukemia and on a particularly aggressive form of leukemia mostly affecting pediatric patients known as Mixed Lineage Leukemia. In 2017 she was awarded the John Goldman Fellowship for translational Hematology. *maria.esposito@roehampton.ac.uk 